\title{
Shaker Flask or Roller Bottle Culture Biosynthesis
}

National Cancer Institute

\section{Source}

National Cancer Institute. Shaker Flask or Roller Bottle Culture Biosynthesis. NCI

Thesaurus. Code C112962.

A process that synthesizes a material of interest using shaker flask or roller bottle cell culture. 